DOI 10.22363/2312-8631-2017-14-3-317-323

УДК $378+81-13+004$

\title{
APPLICATION OF ICT FOR FOSTERING TOLERANCE THROUGH IMPACT ON EMOTIVITY OF LEARNERS
}

\author{
O.V. L'vova \\ Moscow city pedagogical university \\ Sheremetyevskaya str., 29, Moscow, Russia, 127521
}

The search for ways and means of solving the tolerance problem is now extremely urgent for the world community. In Russia due to a number of circumstances for a considerable time some experience has been accumulated and proposed various approaches to solving such problems. Based on the research of V.I. Shakhovsky, who has studied the phenomenon of the emotivity and the possibility of impact on the personal qualities of the individual by means of it and wide spread of information and communication technologies, the author suggests an innovative method for fostering and development of tolerance by influence on emotivity of learners with situative vocabularies and linguistic quasi-corps in the telecommunicative media. Situative vocabulary is an ICT tool that contains lexical structures used in specific communicative situations as well as modern ICT tools (blogs, chats, forums, mail, etc.) to supplement existing material and to discuss the ways and situations of use of various linguistic constructions or meanings of the words. Linguistic quasi-corps is an array consisting of a text (or texts), selected on any basis and includes a small (2-20) number of elements. The main task of linguistic quasi-corps is to help the user in analyzing the structure and/or vocabulary of a document while drafting own document. Experience in application of the ICT tools gives evidence of increase in motivation of students by involving them in active work in familiar to them media in particular social networks.

Key words: Emotivity, tolerance ICT-technologies, linguistic quasi-corpus, situative vocabulary

Nowadays people all over the world face problem of peaceful co-existence. Different countries are of different political systems and level of economical development also differs very much. Moreover population of one and the same country can be of many different nationalities and not only speak different languages but also have different cultural traditions (for example, India or Russia). People of the same settlement can belong to different religions (like in Northern Ireland or Syria). Contradictory trends can exist even inside one religion (for example, Shiites and Sunnis in Islam). Immigration aggravated by military actions and orange revolutions at the Middle East is constantly worsening the situation. Tensions among different countries of the world and different groups of people inside one country exacerbate and often result in bloody conflicts. This in turn actualizes problem of fostering tolerance. It is obvious that solution of the problem demands combined efforts in different activities. Let us consider contribution that can be made by linguistic tools using modern ICT-technologies. What are such tools and how linguistics can help in fostering tolerance?

The concept of tolerance and ideas about ways of its fostering are rather ambiguous. The concept has started to be used in Russia relatively recently, despite its obvious 
relevance. In the article tolerance is understood as active moral position and psychological readiness for bearing in the name of mutual understanding between peoples, social groups, positive interaction with people of different cultural, national, religious or social environment.

Psychologists have proved that by means of emotions emotional attitude to reality of a man is reflected in his mind. Thinking a man as a linguistic personality (LP) "learns" and "interiorizes" information about the surrounding world, reflecting the results of the "interiorization" in the language. Emotions being a mediator between reality and its linguistic reflection regulate the process.

V.I. Shakhovsky [12] started to work out approaches to solve the problems of emotional conceptosphere and other emotional determinants of intra and intercultural communicative factor (for example, emotional behavior, emotional tolerance etc.). According to him [12] emotion is a category of psychology, and the linguistic level emotions are transformed in emotivity. The emotive meaning of a word is not a reflection of the emotions just this speaker. It is not an individual, and is a generalized reflection of the social emotions. And in this respect it also has a social nature, as an indicative value and is correlated with the appropriate emotions of any native speaker. The main characteristic for attribution of the word to the category of emotive is a functional characteristic, if the word expresses or can express emotions, it is emotive.

Meanwhile the primary function of emotives is an emotional expression: the speaker does not seek to evoke any emotion from the listener (this is the fundamental difference between the emotives of expressive vocabulary, aimed at the addressee). The number of vocabulary emotives especially functional in any language cannot be determined. This suggests the dynamic nature of the emotive component of words semantics that can be reduced, minimized, potentialized. To sum up emotively is "inherent to the language the ability to express by system of its means the emotion as a fact of the psyche; social and individual emotions reflected in semantics of language units" [10].

Based on psycholinguistic studies it is logical to assume that if a language being a way to gain social experience, any experience is fixed in the language units, with the help of which people express and perceive emotions impact on (introduction or substitution, for example) can result in fostering certain behavior or even traits of personality.

During its long history Russia has been facing a lot of problems of inter-ethnic and intercultural communication and has gained some experience in the field of fostering tolerance.

Formation of tolerance includes the following fields:

1) definition of general goals and specific objectives;

2) making acquaint with the system of scientific knowledge on the rights and freedoms of man and peoples, of Nations and their relations, the races and religious denominations;

3 ) creation of civil and human senses and consciousness;

4) development of positive experience of culture for communication with people of different nations, races, religious denominations [9].

For the successful formation of tolerant attitudes on a personal level it's important to know what are the major differences between tolerant and intolerant individuals. G.U. Soldatova designed following the criteria of tolerance and intolerant behavior. They are 
suitable for a variety of groups, ranging from families and school class and to society as a whole, but unfortunately, they do not always appear explicitly, therefore some of them can be seen only by trained and interested observers.

Tolerant approach (by G.U. Soldatova)

- coverage of events of public character, as many people as possible, if it does not contradict their cultural traditions and religious beliefs;

- ability to maintain their traditions for all cultures, presented in the society;

- positive vocabulary in the most vulnerable areas of ethnic, race relations, in gender relations.

Intolerance: (G.U. Soldatova)

- insults, ridicule, an expression of neglect;

- ignoring (denial of conversation, recognition);

- negative stereotypes, bias, prejudice (drafting the generalized opinion of the man belonging to a different culture, gender, race, ethnic group, usually on the basis of negative characteristics);

- ethnocentrism (understanding and appreciation of the phenomena of life through the prism of values and traditions of one's own group as the standard and best compared to other groups);

Considering direct communication (or telecommunication) in any community (class, group, business, friends, etc.), you can highlight certain components of the manifestations of tolerance/intolerance. As an example let us take a piece of advice given to a classmate (see Table).

Tolerant/intolerant way of giving advice to a classmate

\begin{tabular}{|c|c|}
\hline Tolerance & Intolerance \\
\hline Attentive listening to and hearing & Interruption, inability to listen to the interlocutor, impatience \\
\hline Desire to understand & Indifference \\
\hline Advice, offer & Detachment \\
\hline Praise, agreement & Insult \\
\hline Encouragement & Critisism \\
\hline Goodwill & Condemnation \\
\hline Consolation & Morals \\
\hline Respect & Threats \\
\hline Empathy & Caution, warning \\
\hline Support & Order, insructions \\
\hline
\end{tabular}

Certain words and expressions correspond to each of this manifestation. It has been proved in linguistics, that in many languages the emotive lexical units with negative meaning predominate in their quantity over emotive lexical units with positive semantics and often intolerant words and expressions are used not out of speaker's desire to offend but out of his not knowing positive variants. Based on this fact gives we can come to a conclusion that linguistic impact via emotive lexical units with positive meaning can psychologically shift personality to positive attitude. 
Effective teaching tolerance and people of different age groups is a challenge. In its decision can be involved in modern means of information, traditionally used in the education system $[1 ; 2]$. At the same total computerization of society is accompanied by distribution of problems associated with the necessity of tolerance. It is important to understand that, on the one hand, the widest dissemination of information and communication technologies (ICT) has become a catalyst of globalization, when the economic, political and cultural activities go beyond the individual territorial jurisdiction and, accordingly, beyond the nation-state. Modern information technologies give a powerful impetus to expand access to education and training and allow you to create new effective individualized methods of education and upbringing, but the spread of information technology is a threat to the dehumanization of society and the replacement of spiritual values and technological concepts and principles. In this situation, all sectors of education should play a key role in countering the "virtualization" of the world. One can see nearing education and fostering to user, but also the individualization of programs of training and education, through the use of means of information takes place [8].

The authors propose to use ICT tools for fostering and development of tolerance by impact on the emotive component of personality.

Earlier innovative means of situative vocabulary and linguistic quasi-corps were offered, which appearance was possible thanks to the widespread use and development of information and telecommunication technologies.

Situative vocabulary is an ICT tool that contains lexical structures used in specific communicative situations (vocabulary for the situation), (sometimes short extracts from rules of behavior in such situations) and modern ICT tools (blogs, chats, forums, mail, etc.) to supplement existing material and to discuss the ways and situations of use of various linguistic constructions or meanings of the words. More information about the tool and ways of its use can be found in relevant works [3-5].

Linguistic quasi-case is an array consisting of a text (or texts), selected on any basis and includes a small (2-20) numbers of elements. The main task of linguistic quasi-corps is to help the user in analyzing the structure and/or vocabulary of a document in drafting their own document. More information about the ways of creation and the possibilities of this innovative ICT tool can be found in [6] and other works by the author.

Experience indicates a relatively high effectiveness in application of such tools for fostering and development of tolerance [7]. The appropriate application of such tools in social networks can improve the efficiency of methods of fostering and development of tolerance through the creation of relevant linguistic environment, which in turn, according to the laws of neurolinguistics forms a world outlook, a positive or negative attitude towards certain events and phenomena. The authors are sure that use of such tools will bring factors important for development of tolerance into all age groups, especially young people.

However, studies identifying the tools and methods of fostering personal qualities, including tolerance, using the widest opportunities offered by the ICT tools are currently only at the phase of start. This promising and highly relevant direction of research and practical activities will receive dissemination in the nearest future. 


\section{LITERATURE}

[1] Григорьев С.Г., Гриншкун В.В. О разработке учебника «Информатизация образования» // Вестник Московского городского педагогического университета. Серия «Информатика и информатизация образования». 2005. № 1 (4). С. 24-28.

[2] Григорьев С.Г., Гриншкун В.В. Цели, содержание и особенности подготовки педагогов в области информатизации образования в магистратуре педагогического вуза // Вестник Московского городского педагогического университета. Серия «Информатика и информатизация образования». 2013. № 1 (25). С. 10-18.

[3] Львова О.В. Воспитательные функции педагогики в условиях информатизации лингвистического образования // Информационно-коммуникационные технологии в лингвистике, лингводидактике и межкультурной коммуникации: материалы V Юбилейной международной научно-практической конференции (Москва 7-9 июня 2012 г.). М., 2012. C. $245-254$.

[4] Львова О.В. Ситуативные вокабуляры как инструмент формирования метапредметных знаний и умений // Бюллетень лаборатории математического, естественнонаучного образования и информатизации. Рецензируемый сборник научных трудов. Воронеж: Научная книга, 2012. T. IV. C. 67-73.

[5] Львова О.В. Теория и практика использования электронной почты для воспитательной и учебно-воспитательной работы // Информатика и образование. 2012. № 5. С. 47-50.

[6] Львова О.В. Перевод с использованием информационных и коммуникационных технологий: учебно-методическое пособие. М.: МГПУ, 2013. 58 с.

[7] Львова О.В. І-культура или полное бескультурье? // Магия ИННО: новые технологии в языковой подготовке специалистов-международников: материалы научно-практической конференции к 70-летию факультета международных отношений МГИМО (Москва, 4-5 октября 2013 г.). Т. 1. М.: МГИМО-Университет, 2013. С. 251-255.

[8] Олейникова О.Н., Муравьева А.А., Аксёнова Н.М. Обучение в течение всей жизни как инструмент реализации Лиссабонской стратегии. М.: РИО ТК им. Коняева, 2009. $131 \mathrm{c.}$

[9] Солдатова Г.У., Шайгерова Л.А., Шарова О.Д. Жить в мире с собой и другими: тренинг для подростков. М.: Генезис, 2000. 112 с.

[10] Шаховский В.И. Категоризация эмоций в лексико-семантической системе языка. Воронеж: Изд-во Воронеж. гос. ун-та, 1987. 190 с.

[11] Шаховский В.И. Филология Philologica. Краснодар, 1995. № 7. С. 13.

[12] Шаховский В.И. Что такое лингвистика эмоций? М.: Русистика, 2008. Вып. 8. С. 4-7.

(C) L’vova O.V., 2017

\section{Article history:}

Received: 20 April, 2017

Accepted: 23 May, 2017

For citation:

L'vova O.V. (2017) Application of ICT for fostering tolerance through impact on emotivity of learners. RUDN Journal of Informatization Education, 14 (3), 317-323. DOI 10.22363/2312-8631-201714-3-317-323

\section{Bio Note:}

Lvova Olga Vladimirovna, candidate of pedagogical sciences, associate professor for the chair of informatization of education of the Moscow city pedagogical university. Contact information: e-mail: olglvova@yandex.ru 


\title{
ИСПОЛЬЗОВАНИЕ ИКТ ДЛЯ ФОРМИРОВАНИЯ ТОЛЕРАНТНОСТИ ПОСРЕДСТВОМ ВОЗДЕЙСТВИЯ НА ЭМОТИВНОСТЬ ОБУЧАЕМЫХ
}

\author{
О.В. Львова \\ Московский городской педагогический университет \\ Шереметьевская ул., 29, Москва, Россия, 127521
}

\begin{abstract}
Поиск путей и средств решения проблемы толерантности является в настоящее время крайне актуальным для всего мирового сообщества. В России в силу целого ряда обстоятельств на протяжении значительного времени накоплен некоторый опыт и предложены различные подходы к решению подобных проблем. Опираясь на исследования В.И. Шаховского, который изучал явление эмотивности и возможности воздействия с ее помощью на личностные качества индивида, и учитывая широкое распространение информационных и телекоммуникационных технологий автор предлагает инновационный метод формирования и развития толерантности путем воздействия на эмотивность обучаемых с помощью ситуативных вокабуляров и лингвистических квази-корпусов в телекоммуникационных средах. Ситуативный вокабуляр представляет собой ИКТ инструмент, содержащий лексические конструкции, применяемые в конкретных коммуникативных ситуациях а также современные ИКТ-инструменты (блоги, чаты, форумы, рассылки и т.д.), позволяющие дополнять имеющийся материал и обсуждать способы и ситуации применения различных лингвистических конструкций или значения слов. Лингвистический квази-корпус - это массив, состоящий из текстов (или отрывков текстов), отобранных по какому-либо признаку и включающий в себя небольшое (2-20) количества элементов. Основной задачей лингвистического квази-корпуса является помощь пользователю в анализе структуры и/или вокабуляра какого-либо документа при составлении собственного документа. Опыт использования данных ИКТ-инструментов свидетельствует о повышении мотивированности обучаемых за счет вовлечения их в активную деятельность в привычных для них средах, в частности социальных сетях.
\end{abstract}

Ключевые слова: эмотивность, толерантность, ИКТ-технологии, лингвистические квазикорпусы, ситуативные вокабуляры

\section{REFERENCES}

[1] Grigor'ev S.G., Grinshkun V.V. O razrabotke uchebnika «Informatizacija obrazovanija» [About development of the textbook "Education Informatization"]. Vestnik Moskovskogo gorodskogo pedagogicheskogo universiteta. Serija «Informatika i informatizacija obrazovanija» [Bulletin of the Moscow city pedagogical university. "Informatics and Informatization of Education" series]. 2005. No. 1 (4). Pp. 24-28.

[2] Grigor'ev S.G., Grinshkun V.V. Celi, soderzhanie i osobennosti podgotovki pedagogov v oblasti informatizacii obrazovanija $v$ magistrature pedagogicheskogo vuza [The purposes, contents and features of training of teachers in the field of informatization of education in a magistracy of pedagogical higher education institution]. Vestnik Moskovskogo gorodskogo pedagogicheskogo universiteta. Serija «Informatika i informatizacija obrazovanija» [Bulletin of the Moscow city pedagogical university. "Informatics and Informatization of Education" series]. 2013. No. 1 (25). Pp. $10-18$.

[3] L'vova O.V. Vospitatel'nye funkcii pedagogiki v uslovija h informatizacii lingvisticheskogo obrazovanija [Educational functions of pedagogics in the conditions of informatization of linguistic education]. Informacionno-kommunikacionnye tehnologii v lingvistike, lingvodidaktike i mezhkul'turnoj kommunikacii: materialy V Jubilejnoj mezhdunarodnoj nauchno-prakticheskoj konferencii (Moskva 7-9ijunja 2012g.) [Information and communication technologies in linguistics, a lingvodidaktika 
and cross-cultural communication: materials $\mathrm{V}$ of the Anniversary international scientific and practical conference (Moscow on June 7-9, 2012)]. M., 2012. Pp. 245-254.

[4] L'vova O.V. Situativnye vokabuljary kak instrument formirovanija metapredmetnyh znanij i umenij [Situational vokabulyara as instrument of formation of metasubject knowledge and abilities]. Bjulleten' laboratorii matematicheskogo, estestvennonauchnogo obrazovanija i informatizacii. Recenziruemyj sbornik nauchny trudov [Bulletin of laboratory of mathematical, natural-science education and informatization. The reviewed collection of scientific works]. Voronezh: Nauchnaja kniga, 2012. T. IV. S. 67-73.

[5] L'vova O.V. Teorija i praktika ispol'zovanija jelektronnoj pochty dlja vospitatel'noj i uchebnovospitatel'noj raboty [The theory and practice of use of e-mail for educational and teaching and educational work]. Informatika i obrazovanie [Informatics and education]. 2012. No. 5. Pp. 4750 .

[6] L'vova O.V. Perevod sispol'zovaniem informacionnyh i kommunikacionnyh tehnologij [The translation with use of information and communication technologies]: uchebno-metodicheskoe posobie. M.: MGPU, 2013. 58 p.

[7] L'vova O.V. I-kul'tura ili polnoe beskul'tur'e? [I-culture or full lack of culture?]. Magija INNO: novye tehnologii v jazykovoj podgotovke specialistov-mezhdunarodnikov: materialy nauchnoprakticheskoj konferencii $k$ 70-letiju fakul'teta mezhdunarodnyh otnoshenij MGIMO (Moskva, 4-5oktjabrja 2013g.) [INNO magic: new technologies in language training of specialists foreign affairs specialists: materials of a scientific and practical conference for the 70 anniversary of faculty of the international relations of MGIMO (Moscow, on October 4-5, 2013)]. T. 1. M.: MGIMOUniversitet, 2013. Pp. 251-255.

[8] Olejnikova O.N., Murav'eva A.A., Aksjonova N.M. Obuchenie v techenie vsej zhizni kak instrument realizacii Lissabonskoj strategii [Training during all life as the instrument of realization of the Lisbon strategy]. M.: RIO TK im. Konjaeva, 2009. 131 p.

[9] Soldatova G.U., Shajgerova L.A., Sharova O.D. Zhit'v mire s soboj i drugimi [Zhit in the world with and others]: trening dlja podrostkov. M.: Genezis, 2000. 112 p.

[10] Shahovskij V.I. Kategorizacija jemocij v leksiko-semanticheskoj sisteme jazyka [A categorization of emotions in lexico-semantic system of language]. Voronezh: Izd-vo Voronezh. gos. un-ta, 1987. $190 \mathrm{p}$.

[11] Shahovskij V.I. Filologija Philologica [Philologica philology]. Krasnodar, 1995. No. 7. Pp. 13.

[12] Shahovskij V.I. Chto takoe lingvistika jemocij? [What is linguistics of emotions?]. M.: Rusistika, 2008. No. 8. Pp. 4-7.

\section{История статьи:}

Дата поступления в редакцию: 20 апреля 2017

Дата принятия к печати: 23 мая 2017

Для цитирования:

Львова О.В. Использование ИКТ для формирования толерантности посредством воздействия на эмотивность обучаемых // Вестник Российского университета дружбы народов. Серия «Информатизащия образования». 2017. Т. 14. № 3. C. 317-323. DOI 10.22363/2312-86312017-14-3-317-323

\section{Сведения об авторе:}

Львова Ольга Владимировна, кандидат педагогических наук, доцент кафедры информатизации образования Московского городского педагогического университета. Контактная информация: e-mail: yandex.ru 